\title{
Two Adpositional Predicates in Mayrinax Atayal- predicate selection and further implications
}

\author{
Zong-Rong Huang
}

In this paper, I propose that existentials (1a), predicative locatives (1b), and possessives (1c) in Mayrinax Atayal, an ergative Formosan language (Huang 1994; Starosta 1999; cf. Aldridge 2004), all share a locative origin (Freeze 1992), showing two subject positions across the existential closure (Diesing 1992). I also argue that kiya/haniyan are complex adpositional predicates derived from head incorporation to explain predicate selection, supporting den Dikken (2006).

$\begin{array}{lllll}\text { a. Kiya /haniyan } & \text { a } & \text { ruwas } & \text { cku' } & \text { raralan } \\ \text { EXIST } & \text { IND.ABS } & \text { book } & \text { OBL } & \text { desk }\end{array}$

'There is a/some book on the desk.'
b. Kiya/haniyan cku' raralan $\mathrm{ku}$ ngiyaw
EXIST OBL desk DEF.ABS cat

'The cat is on the desk.'
c. Kiya/haniyan a pila ni Payan
EXIST IND.ABS money ERG PN
'Payan has money.'

First, kiya/haniyan is a non-verbal, adpositional predicate showing no voice alternation or TAM affixation (2a-b), and it assigns inherent oblique case to locative DPs (1a-b), with the ergative case in (1c) from an adpositional source (cf. Mahajan 1997).

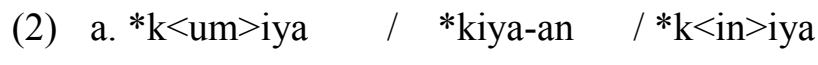

$$
\text { EXIST }<\text { AF }>\quad \text { EXIST-LF } \quad \text { EXIST }<\text { Perf }>
$$

$$
\begin{aligned}
& \text { b. }{ }^{*} \mathrm{~h}<\text { um }>\text { ani / *hani-un / *si-hani / *pa-hani } \quad / * \mathrm{~h}<\text { in }>\text { ani } \\
& \text { EXIST }<\text { AF }>\text { EXIST-PF BF-EXIST FUT.AF-EXIST EXIST }<\text { Perf }>
\end{aligned}
$$

Second, the absolutive DP is structurally higher than the locative DP, with evidence from quantifier scope and superiority.

(3) a. Kiya a tugal ka ruwas cku' kahavag ka raralan 
EXIST IND.ABS three LK book OBL all LK desk

'There are three books on all the desks.' $\quad(3>$ all; \#all $>3)$

b. ? Nanuwan ku kiya i inu

what DEF.ABS EXIST OBL where

(intended: 'What is where?')

b'.**(I) inu ku kiya a nanuwan

OBL where DEF.ABS EXIST IND.ABS what

(intended: 'Where is what?')

(4) a. Kiya cku' kahavag ka kahuniq ku tugal ka bhut

EXIST OBL all LK tree DEF.ABS three LK squirrel

'Three squirrels are in all the trees.' (3>all; \#all $>3)$

b. ? Ima ku kiya i inu

who DEF.ABS EXIST OBL where

(intended: 'Who is where?')

b'.**(I) inu ku kiya ku ima

OBL where DEF.ABS EXIST DEF.ABS who

(intended: 'Where is who?')

Yet, evidence from Q-floating (cf. Sportiche 1988) and definiteness constraint shows that the existential subject is within the nuclear scope (pP in this study) while the locative subject is out of it (5a-a'; 5b-b'). The DP order is indeed not free (contra Zeitoun et al. 1999).

(5) a. Kiya (kahavag) cku' kahoniq (kahavag) ku bhut EXIST all OBL tree all DEF.ABS squirrel

'All the squirrels are in the trees.'

$\begin{array}{clcccc}\text { a'. Kiya (tiqay) a } & \text { ruwas } & \text { ?*(tiqay) } & \text { cku' } & \text { naniqan } \\ \text { EXIST some } & \text { IND.ABS } & \text { book } & \text { some } & \text { OBL } & \text { desk }\end{array}$

'There are some books on the desk.'

b. Kiya cku' kahuniq ku bhut=haca

EXIST OBL tree DEF.ABS squirrel=that 
'That squirrel is in the tree.'

$$
\begin{aligned}
& \text { b'. ?* Kiya a ruwas=haca cku' naniqan } \\
& \text { EXIST IND.ABS book=that OBL desk }
\end{aligned}
$$

'There is that book on the desk.'

I propose a unified analysis for the existentials, predicative locatives, and possessives in Mayrinax Atayal that they are derived from a complex adpositional projection [pP theme [p(lace) [P [ locative]]]] (cf. den Dikken 2006), also a nuclear scope. The $\mathrm{p}$ (lace) head is assumed to house a [distal]/[proximal]feature that selects kiya $(\mathrm{P}+[$ distal $] \mathrm{p})$ or haniyan $(\mathrm{P}+[$ proximal $] \mathrm{p})$, its adpositional equivalent with proximal semantics (Huang 1995, 2000).

The derivation for the three constructions proceeds as follows: P assigns inherent oblique case to the locative DP, and $p$ introduces the theme subject forming a nuclear scope pP. In predicative locatives, $\mathrm{T}$ probes for the theme to checks the [Abs] feature, [EPP] carried by $\mathrm{C}$ attracts it to [Spec, $\mathrm{C}$ ]. In existentials, $\mathrm{T}$ checks [Abs] of theme but C carries no EPP to attract it out of the nuclear scope (Diesing 1992). In possessives, the human locative DP, assigned ergative case (cf. Mahajan 1997; Markman \& Grashchenkov 2012), attaches to the theme DP due to its clitic nature. The complex P moves to a head position below T. The structure undergoes TP-movement to [Spec,C] when merged with $\mathrm{C}$ for the predicate-initial word order, following Aldridge (2004).

This analysis supports (i) the locative-based analysis (Freeze 1992), (ii) his HAVE/BE hypothesis for Mayrinax Atayal lacks HAVE because the adoposition does not reach T/INFL-related heads, (iii) the complex locative adposition hypothesis (den Dikken 2006) for kiya/haniyan selection, and (iv) the dual-subject hypothesis (Guilfoyle et al. 1992). The dual subject fact questions Aldridge (2004) that absolutive DPs in Austronesian languages are unbiasedly attracted to the CP domain as a presuppositional element, if specificity or categorial EPP (cf. Laka 1993) is not taken into consideration.

\section{Abbreviations:}

ABS: absolutive case, AF; Agent Focus; BF: Beneficiary Focus; DEF: definite; ERG: ergative case; FUT: future tense; IND: indefinite; LF: Locative Focus; LK: linker; OBL: oblique case; Perf: perfective aspect; PF: Patient Focus; PN: proper name 


\section{References}

Aldridge, E. 2004. Ergativity and Word Order in Austronesian Languages. Ph.D. dissertation, Cornell University.

Diesing, M. 1992. Indefinites. Cambridge, MA: The MIT Press.

Den Dikken, M. 2006. On the functional structure of locative and directional PPs. Ms. CUNY Graduate Center.

Freeze, R. 1992. Existentials and other Locatives. Language 68.3: 553-595.

Guilfoyle, E., H. Hung, and L. Travis. 1992. Spec of IP and Spec of VP: Two Subjects in Austronesian Languages. Natural Language and Linguistic Theory 10: 375-414.

Huang, M. 1994. Ergativity in Atayal. Oceanic Linguistics., 33.1, 129-143.

Huang, M. 1995. A study of Mayrinax Syntax. Taipei, Taiwan: Crane Publishing. Huang, M. 2000. A Reference Grammar of Atayal. Taipei, Taiwan: Yuanliu. Laka, I. 1993. Unergatives that Assign Ergative, Unaccusatives that Assign Accusative. MIT Working Papers in Linguistics 18: 149-172.

Mahajan, A. 1997. Universal Grammar and the Typology of Ergative Languages. In Studies on Universal Grammar and Typological Variation (eds.) by A. Alexiadou and T. A. Hall, 35-57. Amsterdam: John Benjamins Publishing.

Markman, V. G. and Grashchenkov, P. 2012. On the adpositional nature of ergative subjects. Lingua., 122.3: 257-66.

Sportiche, D. 1988. A Theory of Floating Quantifiers and its Corollaries for Constituent Structure. Linguistic Inquiry., 19, 425-49.

Starosta, S. 1999. Transitivity, Ergativity, and the Best Analysis of Atayal Case Marking. In E. Zeitoun and P. J. Li (eds.), Selected Papers from the Eighth International Conference on Austronesian Linguistics (pp. 371-392). Taipei, Taiwan : Academia Sinica.

Zeitoun, E., Huang, L. M., Yeh, M. M. \& Chang, A. H. (1999). Existential, Possessive, and Locative Constructions in Formosan Languages. Oceanic Linguistics, 38.1: 1-42.

Zong-Rong Huang

National Taiwan University

Graduate Institute of Linguistics

3F, Le-xue Building, No.1, Sec. 4, Roosevelt Road, Taipei, Taiwan.

r99142002@ntu.edu.tw 